九州大学学術情報リポジトリ

Kyushu University Institutional Repository

\title{
Attitude toward Bioremediation-Related Technology and Relation with Company Social Responsibility
}

Kitjanukit, Santisak

Graduate School of Engineering, Kyushu University

https://doi.org/10.5109/2349300

出版情報 : Evergreen. 6 (3)，pp.240-245，2019-09. 九州大学グリーンテクノロジー研究教育センター バージョン：

権利関係 : 


\title{
Attitude toward Bioremediation-Related Technology and Relation with Company Social Responsibility
}

\author{
Santisak Kitjanukit \\ Graduate School of Engineering, Kyushu University, Japan \\ *Author to whom correspondence should be addressed, \\ E-mail: ming@mine.kyushu-u.ac.jp
}

(Received March 31, 2019; accepted August 30, 2019).

\begin{abstract}
For sustainable wastewater treatment, bioremediation technology was introduced. Due to its complexity, peoples being skeptical and start to refuse. This making the installation of such technology become more difficult. To prevent conflict between the company and the local, public acceptance is needed to be evaluated and improved. CSR activity was found to be a booster promoting a trust toward the company, it is expected to boost positive perception as well. This study surveyed the attitude toward bioremediation and CSR activity participation. Data analysis found that people believe that bioremediation is an environmental-friendly approach and is a long-term solution for wastewater treatment. Peoples with CSR activity experience tended to have higher positive perception score than non-experienced. The results illustrated that if the company giving accurate, adequate information and doing appropriate CSR activity, social's positive perception toward bioremediation could be improved.
\end{abstract}

Keywords: bioremediation, positive perception, company social responsibility

\section{Introduction}

Owing to a rapid increase in industrialization, polluted environment is becoming a serious problem we are facing. Remediation is an action that deals with the removal of pollutants or contaminants and restoration. Remediation by means of chemical is quick and have certain results. However, it could cause secondary wastes due to the accumulation of residues.

Bioremediation is a technique that makes use of living organism by stimulated their growth and utilized metabolism to degrade the target pollutants ${ }^{1}$. Bioremediation has been proven effective and reliable at a very low cost than its parallel conventional technology in most cases $^{2}$. It is estimated to cost just one-third of the cost of incineration/excavation and one-half of the cost of chemical-based remediation ${ }^{3)}$. Moreover, the by-products from bioremediation could be utilized for other purposes; for example, anaerobic digestion of municipal/agricultural wastes could be utilized methane gas production ${ }^{4,5)}$ for electricity generation and bio-hydrogen production ${ }^{6,7)}$ for the future fuels. The main drawback of bioremediation is that the process is complex and time-consuming.

One of the main dragging force stopping bioremediation from pilot-scale to full-scale is social factors. Acceptance of new technology by the public is difficult to predict. People often being skeptical of this technology because of inadequate knowledge and information about how it works and start to refuse.
Therefore, installation of bioremediation-related technology is difficult and often introduce conflict with residents. Acquisition of public acceptance is challenging and on a psychological basis, it often deals with attitude. There are several factors positively affecting people attitude toward something, which included perceived benefit, risk acceptance, familiarity and encouragement ${ }^{8}$. Social acceptance could be boost-up via encouragement, one of the popular strategies.

Company social responsibility (CSR) refers to the ethical principle that an organization should be responsible for how its behavior might affect society and the environment ${ }^{9}$. CSR activity could somehow conciliate the argument between the company and the villagers. Most consumers think companies should try to improve society and the environment along with achieving their business goals. They also believe companies doing charity work will receive a positive response ${ }^{10,11)}$. CSR activity is a good example of encouragement strategy that boosts people's trust toward the company in one-way or another ${ }^{12,13}$. Because bioremediation is complex and difficult to understand, people tend to base their decision on the trust of the company responsible.

Previously, a study published by Antje Simon ${ }^{14)}$ presented the social aspect of CSR and biotechnology. However, direct evidence such as questionnaire-based study for the relatedness of CSR and biotechnology is limited. With the aim to encourage the installation of bioremediation technology, this research surveyed the 
attitude toward bioremediation technology, CSR activity participation and drawing the relation between them.

\section{Materials and methods}

\subsection{Questionnaire}

Paper-based and Internet-based questionnaires were created to gather information on local perception toward bioremediation technology. The survey asked residents to rate their satisfaction on their current community, basic knowledge of bioremediation, perception toward bioremediation, and experience on CSR activity. The questionnaire was randomly distributed to peoples of a different nationality, age, and education background.

\subsection{Sample}

In a total of 50 , the sample comprised of female (24; $48 \%)$, male $(20 ; 40 \%)$, and prefer not to say $(6 ; 12 \%)$ from age range of $20-25(12 ; 24 \%), 26-30$ (28; 56\%), 31-40 (4; $8 \%)$, and $>41(6 ; 12 \%)$. Major nationality of the population is Thai (47\%), Japanese (29\%), and Indonesian $(18 \%)$ with minor from Salvadorean, Tunisian, Ukrainian (each $2 \%$ ). The current career of the population is varied from a student (32\%), employee (28\%), government officer $(10 \%)$, own business $(2 \%)$, other $(14 \%)$, and unemployment (14\%). The educational background of the population is mainly graduated school $(50 \%)$, followed by bachelor's degree (34\%), Ph.D. (10\%), high school (2\%) and other $(4 \%)$.

\subsection{Grading}

The attitude toward bioremediation technology was collected quantitatively via statements in the questionnaire. The statements including (i) bioremediation is an environmental-benign approach, (ii) bioremediation is a long-term solution for wastewater treatment, (iii) bioremediation is a high cost-value approach, (iv) bioremediation could cost spreading of microbe problem, (v) bioremediation could cost antibiotic-resistance problem. To compare between each factor, the data was converted to quantitative data as followed; 'agree', 'neutral', 'I don't know', and 'disagree' on each of the questions were marked with $+3,+1,0$, and -3 , respectively. The average and standard deviation of the sum of the score were compared between CSR experienced and non-CSR experience groups.

\subsection{Secondary data mining}

CSR reports from various companies was reviewed and categorized into five categories; Environment, health $\&$ medical cares, scholarship \& education, social welfare, and others.

\section{Results and discussion}

\subsection{Level of positive perception toward bioremediation technology}

A questionnaire was constructed and distributed to measure the perception toward bioremediation technology. The participants were asked to rate their attitude toward bioremediation through five statements mentioned in section 2.3.

Among the sample population regardless of the age range, most of them agree that bioremediation is an environmentally friendly approach. People might not actually understand what bioremediation is, but the word 'Bio-' made it feels soft and safe (personal communication). The perception turned a bit negative when it came to the cost-value of bioremediation (Fig. 1). This might due to the fact that the effects of the technology should be visible in order to encourage people's positive perception ${ }^{15)}$. Not every payer got the benefit from the technology and someone might be excluded as well (comment from the survey). When the possibility of microbe spreading problem was asked in question IV, answer trend was observed. Younger samples had more positive (not agree) about this statement, whereas older samples tend to agree with the statement (negative). A similar trend was also observed in question $\mathrm{V}$ but responses on 'I don't know' were significantly increased. Question IV and V required some knowledge about how bioremediation work which might not mention in general. Peoples may skeptical on biotechnology because of inadequate information, and experience.

From this survey, peoples believe that bioremediation is an environmentally friendly approach and is a long-term solution for wastewater treatment. However, there are some concerns regarding the technology due to inadequate information that might negatively influent the attitude.

After grading (mentioned in section 2.3), positive perception score from each occupation was compared. With a maximum score of 15 , the average positive perception score is 9 (pooled). Among all occupation, the student has the highest average score and government officer has the largest deviation. Different occupations could affect people's perception toward something. The student might only receive one-sided information (ex; advantages) which reflected in relatively high positive perception score (Fig. 2). Depending on affiliation, those government officers may have a different attitude toward bioremediation influenced from the information they received which reflected in large deviation (Fig. 2).

The previous study on the acceptance of gene technology has shown information sources has a notable impact on people's perception either positive or negative ${ }^{16)}$. By providing accurate and enough information on how bioremediation work, peoples can criticize or assess both risks and benefits of it. Positive perception score could be improved. 


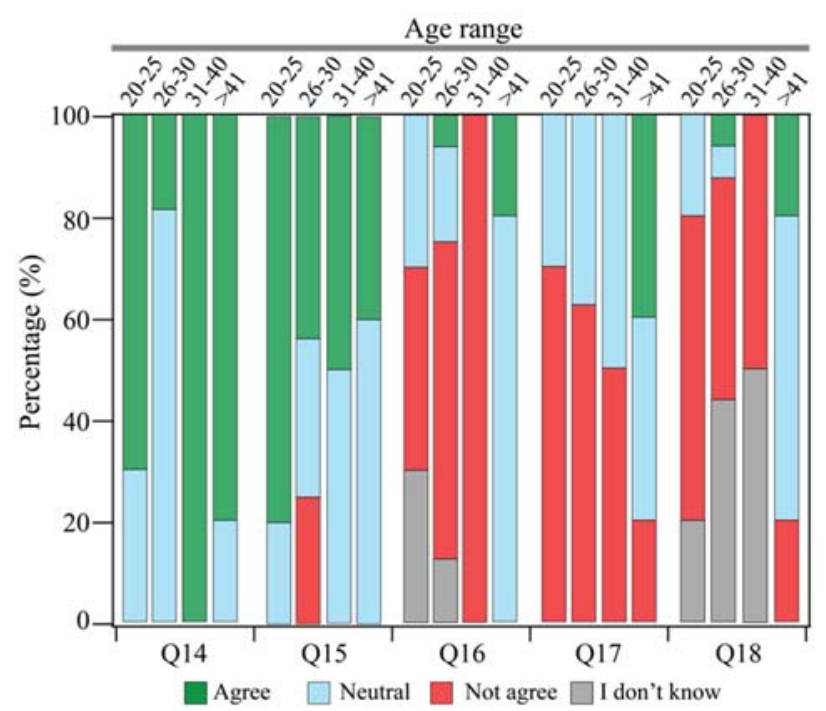

Q14 Bioremediation is environmental friendly approach

Q15 Bioremediation is a long-term solution for wastewater treatment Q16 Bioremediation is a high cost-value approach

Q17 Bioremediation could cost spreading of microbe problem

Q18 Bioremediation could cost antibiotic-resistance problem

Fig. 1: Perception of bioremediation technology among sample in each age range

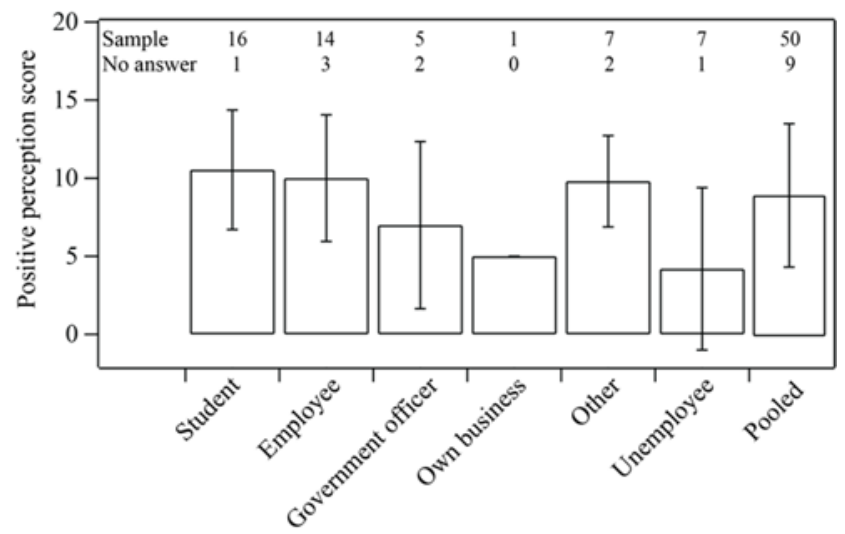

Fig. 2: Positive perception toward bioremediation related technology among occupation

\subsection{CSR management; case studies from different companies}

Each company has its own policy for CSR activity as well as CSR report. It was found that mostly CSR activity from a company related to what the company is doing. The example of CSR activity was summarized in table 1 . HITACHI company (as of 2016) mostly spent their CSR funding on scholarship and research grants. McDonald Japan (as of 2016), as a food service company, its CSR activity was focused on food and health-related. For a cosmetic company like Shiseido, handcare and cover makeup activity could tighten the bond between company and community as well as among employees ${ }^{17,18)}$. By the way, the company could also advertise their product through those activities. Bio-Yu ${ }^{19)}$ (bio-foot bath) by Swing corporation, a water solution company, is one of the good examples for encouragement; one of the strategies used by many to positively influent people's perception $^{8)}$. The water was heated by biogas produced from municipal wastewater treatment. The local resident could freely use this amenity so that they can feel more familiar with biomass energy. By the way, the name "BioYu" was given by the local; thus, this indicated the popularity of this recreation spot. The residents get to know to biotechnology through leisure or what they familiar with.

The common CSR activity such as cleaning and reforestation could somehow reflect how the company values the importance of the environment.

\subsection{CSR activity participation}

This section of the questionnaire allowed the respondent to answer in multiple selections. Breakdown of CSR activities participated by the survey population was shown in Fig. 3. Mainly, samples participated in the education category of CSR activity (50\%). This might be because it is variety and relatively easy to participate. Most respondents that experienced in reforestation often had experienced in slum improvement, and vice versa (each 16\%). For rehabilitation, this category required experienced or trained participant because it deals with psychological sensitive victims (e.g., disaster victim, injured labors).

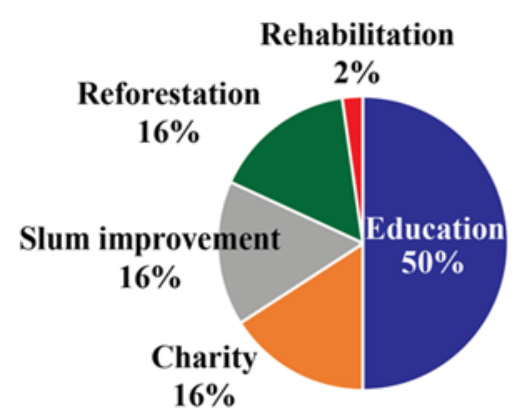

Fig. 3: Category of CSR activity participated by the survey population

According to the survey, the company could positively boost its image through education and reforestation categories. 
Table 1. Breakdown of CSR activity

\begin{tabular}{|c|c|c|c|c|c|}
\hline Company & Environment & $\begin{array}{l}\text { Health \& } \\
\text { Medical care }\end{array}$ & $\begin{array}{c}\text { Scholarships \& } \\
\text { education }\end{array}$ & Social welfare & Others \\
\hline Hitachi $(2016)^{20)}$ & $\begin{array}{l}\text { - Environment } \\
\text { education } \\
\text { - Green project } \\
\text { - Cleaning } \\
\text { activities }\end{array}$ & - & $\begin{array}{l}\text { - Open innovation } \\
\text { - Research grants } \\
\text { - Scholarships }\end{array}$ & - Disaster relief & - Human right \\
\hline $\begin{array}{l}\text { McDonald Japan } \\
(\mathbf{2 0 1 6})^{21)}\end{array}$ & $\begin{array}{l}\text { Reduce energy } \\
\text { usage per } \\
\text { customer. } \\
\text { Reduce waste } \\
\text { amount }\end{array}$ & $\begin{array}{l}\text { Sports support: } \\
21,000 \text { teams of } \\
\text { baseball and } \\
\text { football across } \\
\text { Japan } \\
\text { - QR code } \\
\text { information: } \\
\text { allergy, country of } \\
\text { origin, and } \\
\text { nutritional } \\
\text { information }\end{array}$ & $\begin{array}{l}\text { Hamburger } \\
\text { University } \\
\text { (Educational } \\
\text { institution) }\end{array}$ & $\begin{array}{l}\text { Education support } \\
\text { (food education } \\
\text { support) }\end{array}$ & $\begin{array}{l}\text { Charity: } \\
\text { 70,020,000 yen } \\
\text { (collected from } \\
\text { donation) for } \\
\text { 7,453 family users }\end{array}$ \\
\hline $\begin{array}{l}\text { The Coca-Cola } \\
\text { Japan company } \\
(\mathbf{2 0 1 8})^{22)}\end{array}$ & Coastal cleanup & - & - & - & $\begin{array}{l}1 \% \text { of the } \\
\text { company's } \\
\text { operating income } \\
\text { is invested back } \\
\text { into the } \\
\text { community } \\
\text { - Supporting } \\
\text { activities all over } \\
\text { Japan }\end{array}$ \\
\hline $\begin{array}{l}\text { Nippon steel \& } \\
\text { Sumikin } \\
\text { engineering } \\
(\mathbf{2 0 1 5})^{23)}\end{array}$ & $\begin{array}{l}\text { Mangrove } \\
\text { planting involving } \\
\text { participation form } \\
\text { residents }\end{array}$ & - & - & $\begin{array}{l}\text { Nurturing the next } \\
\text { generation; } \\
\text { Passion and } \\
\text { Advanced } \\
\text { technology }\end{array}$ & $\begin{array}{l}\text { Donation of } \\
\text { reusable PCs ( } 80 \\
\text { units) }\end{array}$ \\
\hline Shiseido $^{17)}$ & $\begin{array}{l}\text { - Beach cleaning } \\
\text { - Tree planting }\end{array}$ & Handcare service & - & $\begin{array}{l}\text { Shiseido camellia } \\
\text { fund }\end{array}$ & - \\
\hline Toyota $^{24)}$ & $\begin{array}{l}\text { Reforestation, } \\
\text { environmental } \\
\text { education }\end{array}$ & - & $\begin{array}{l}\text { - Science } \\
\text { workshop } \\
\text { - Research grant } \\
\text { - Toyota safety } \\
\text { school }\end{array}$ & - & - \\
\hline $\begin{array}{l}\text { Swing } \\
\text { corporation }^{19)}\end{array}$ & $\begin{array}{l}\text { Reduce electricity } \\
\text { usage }(50 \%)\end{array}$ & - & - & $\begin{array}{l}\text { - Installation of } \\
\text { foot bath for } \\
\text { public use } \\
\text { - Natural disaster } \\
\text { relief }\end{array}$ & $\begin{array}{l}\text { - Promoting local } \\
\text { production of } \\
\text { biogas (energy } \\
\text { independence } \\
\text { project) }\end{array}$ \\
\hline $\begin{array}{l}\text { Siam Cement } \\
\text { Group (SCG) }\end{array}$ & $\begin{array}{l}\text { Zero waste } \\
\text { community } \\
\text { project }\end{array}$ & - & $\begin{array}{l}\text { Dream } \\
\text { Scholarships in } \\
\text { ASEAN } \\
\text { SCG Future } \\
\text { Engineer Program }\end{array}$ & $\begin{array}{l}\text { - Flood victim } \\
\text { relief } \\
\text { - Slum } \\
\text { improvement }\end{array}$ & - \\
\hline $\begin{array}{l}\text { Petroleum } \\
\text { Authority of } \\
\text { Thailand } \\
\text { (PTT) }^{26)}\end{array}$ & $\begin{array}{l}\text { Reduce } \\
\text { greenhouse gas } \\
\text { emission }(0 \% \\
\text { growth) } \\
\text { Evaluation of } \\
\text { impact on } \\
\text { biodiversity }\end{array}$ & - & $\begin{array}{l}\text { Scholarships } \\
\text { Research grants }\end{array}$ & $\begin{array}{l}\text { - Slum } \\
\text { improvement } \\
\text { (bio-gas system) }\end{array}$ & - \\
\hline
\end{tabular}




\subsection{Relatedness of CSR activity to positive perception toward bioremediation technology}

In the population of 48 (excluding two with no answer), samples experienced CSR activity tend to have positive perception toward bioremediation-related technology (10.04 average points) more than non-CSR activity experienced (6.15 average points) (Fig. 4). Comments from the survey indicated that if comparing two companies, they would rather trust the one doing CSR activity $^{12)}$. It is also indicated that people who have experienced environmental CSR activity tended to have a more positive attitude toward bioremediation technology (Fig. 5). Because bioremediation is complex and difficult to understand, people tend to base their decision on the trust of the company responsible.

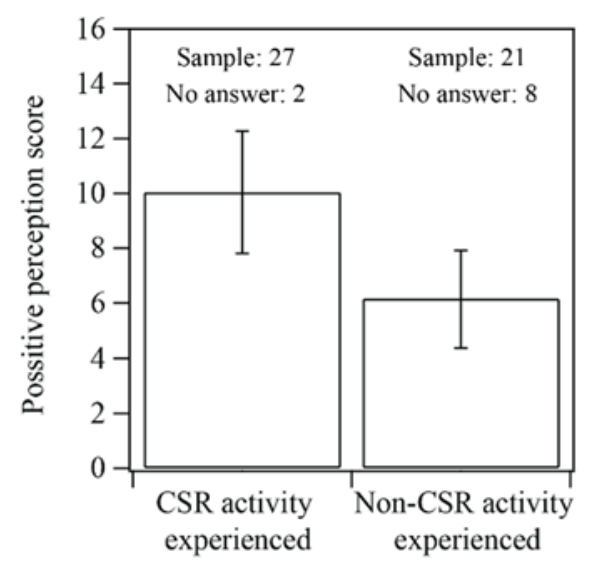

**Population: 50, 2 with no answer

Fig. 4: Average score positive perception toward bioremediation related technology

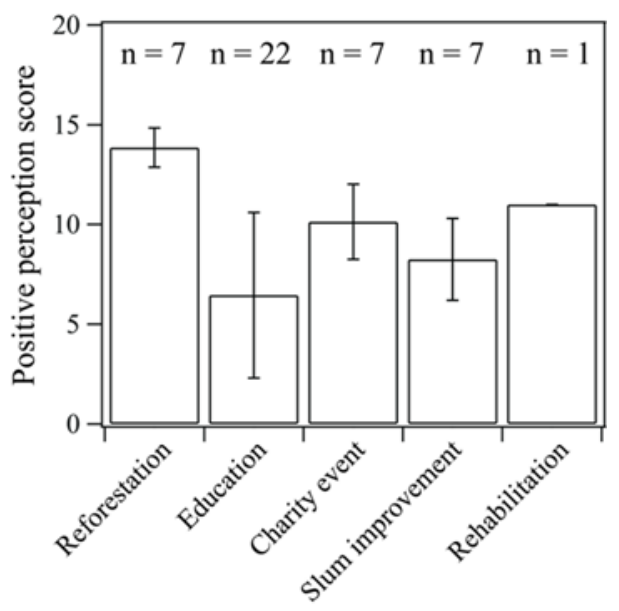

Fig. 5: Positive perception toward bioremediation related to the types of CSR activity participation

From this point, it could be said that by participating in CSR activity, trust is built-up and indirectly influent the positive perception toward bioremediation technology. However, the comparison of people's trust between CSR and non-CSR companies is necessary to strengthen this statement. Also, age and occupation affected strongly on the perception of bioremediation technology. To avoid such factors, purposive sampling on specific age group and occupation should be used.

\section{Conclusions, limitation, and recommendations}

Perception toward bioremediation technology was surveyed from a group of peoples with different age, academic background, and occupation. The studied population's perception is moderately positive (avg. 9). Peoples believe that bioremediation is an environmentalfriendly approach and is a long-term solution for wastewater treatment. The acceptance of this technology is being doubted due to inadequate information.

Type CSR activity differs among companies, but it is somehow related to what the company is doing. Education is the most participated CSR categories according to the survey.

The company which doing CSR activity often gained trust from social. Participants of CSR activity (especially environment category) could experience and build-up

As a result, samples with CSR activity experience tend to have positive perception toward bioremediation.

The limitation influencing this work is the attitude of the author himself. The author's perception toward bioremediation is strongly positive and might occasionally bias the discussion logic.

For further research, to avoid blank response and improve the accuracy, purposive sampling should be used to select the participant of the questionnaire.

\section{Acknowledgment}

The author is grateful for financial assistance provided by the Kyushu University Advanced Graduate Program in Global Strategy for Green Asia.

\section{References}

1) R. Boopathy, Bioresour. Technol, 74, 63-67 (2000).

2) C.C. Azubuike, C.B. Chikere, and G.C. Okpokwasili, World J Microbiol Biotechnol, 32, 180 (2016).

3) C. Jespersen, D.E. Jerger, and J.H. Exner, Chem Eng $J$, 100, 116-122 (1993).

4) D.H. Kim and M.S. Kim, Bioresource Technology, 127, 267-274 (2013).

5) C. Wu, Q. Wang, M. Yu, X. Zhang, N. Song, Q. Chang, M. Gao, and K. Sonomoto, Applied Energy, 155, 846-853 (2015).

6) I. Pecorini, F. Baldi, and R. Iannelli, Sustainability, 11, 622 (2019).

7) G. Yanga and J. Wang, Fuel, 237, 1203-1208 (2019).

8) L. Amin, J.M. Jahi, A.R.M. Nor, M. Osman, and M.M. Nor, Asia Pac. J. Mol. Biol. Biotechnol., 15, 39-51 (2007). 
9) D. Jobber and F. Ellis-Chadwick, Principles and practice of marketing. 7 ed., McGraw-Hill Education, London (2013).

10) E.R. James, Consumers Overwhelmingly Want CSR. [cited 2019; Available from: https://www.forbes.com/sites/csr/2010/12/15/newstudy-consumers-demand-companies-implementcsr-programs/\#78365e7265c7.

11) D. Yoo and J. Lee, Sustainability, 10, 2956 (2018).

12) K. Ramesh, R. Saha, S. Goswami, Sekar, and R. Dahiya, Corporate Social Responsibility and Environmental Management, 26, 377-387 (2019).

13) O.C. Ferrell, D.E. Harrison, L. Ferrell, and J.F. Hair, Journal of Business Research, 95, 491-501 (2019).

14) S. Antje, Corporate Social Responsibility and Biotechnology: identifying social aspects for European biotechnology companies, The international institute for industrial environmental economics, Lund University (2002).

15) S. Kocher, D. Levi, and R. Aboud, J. Appl. Soc. Psychol., 32, 1756-1770 (2002).

16) M. Siegrist, J. Appl. Soc. Psychol., 29, 2093-2106 (1999).

17) Shiseido company official website. [cited 2019; Available from: https://www.shiseidogroup.com/sustainability/com munity/.

18) S. Kang, S.J. Han, and J. Bang, Sustainability, 10, 1650 (2018).

19) Swing Corporation official website. Available from: https://www.swingw.com/company/kankyou_houshin_index.html.

20) HITACHI corporation official website. Available from: https://www.hitachi.co.jp/sustainability/index.html.

21) McDonald Japan official website. [cited 2019; Available from: http://www.mcdonalds.co.jp/company/csr/.

22) The Coca-Cola Japan company official website. [cited 2019; Available from: https://www.cocacola.co.jp/sustainability.

23) Nippon steel \& Sumikin engineering official website. [cited 2019; Available from: https://www.eng.nssmc.com/csr/index.html.

24) Toyota official website. [cited 2019; Available from: https://www.toyotaglobal.com/sustainability/social_contribution/.

25) Siam Cement Group official website (in Thai). [cited 2019; Available from: https://www.scg.com/greenvaluechain/media.

26) Petroleum Authority of Thailand offical website. [cited 2019; Available from: http://www.pttplc.com/en/Sustainability/Pages/susta inability.aspx. 